\title{
The Economic Performance of Small Banks, 1985-2000
}

\author{
William F. Bassett and Thomas F. Brady, of the \\ Board's Division of Monetary Affairs, prepared this \\ article. James E. Cypert, Jr., and Mark J. Gibson \\ provided research assistance.
}

Several trends in the financial industry over the past decade and a half have potentially threatened the competitiveness of small banks. Among these developments are the numerous mergers that increased the size and scope of large banks and greater competition from mutual funds and other nonbank financial institutions. In this article, we examine the economic performance of small banks during the 1985-2000 period by focusing on their ability to attract and profitably intermediate insured and uninsured deposits. ${ }^{\perp}$

We find that the expansion of deposits and assets at small banks, when adjusted to account for the effects of mergers on measured growth, has consistently exceeded the growth at large banks. Moreover, the profitability of small banks has risen to high levels over the period. These indications of strength among small banks as a whole also hold true for subgroups within the small bank sector. The key reasons for the generally good performance of small banks in recent years appear to be their ability to earn relatively high rates of return on their loans and an increase in the share of their portfolios devoted to loans.

1. Except where otherwise indicated, data in this article are from the quarterly Reports of Condition and Income (Call Reports) for the domestic offices of insured domestic commercial banks and nondeposit trust companies (hereafter, banks). The data have been adjusted to take account of mergers.

Bank size categories in this article are based on assets at the start of each quarter as follows: large banks (those ranked 1 through 100), medium (101 through 1,000), and small. At the start of the fourth quarter of 2000 , large banks were those with assets of at least $\$ 6.94$ billion; medium, $\$ 331$ million to $\$ 6.93$ billion; and small, less than \$331 million. For more on the economic performance of banks over the 1985-2000 period, see, for 2000, William F. Bassett and Egon Zakrajsek, "Profits and Balance Sheet Developments at U.S. Commercial Banks in 2000," Federal Reserve Bulletin, vol. 88 (June 2001), pp. 367-93 (www.federalreserve.gov/pubs/bulletin), and the corresponding article in one of the June-September issues of the Federal Reserve Bulletin in each of the earlier years.

\section{RECENT TRENDS AFFECTING SMALL BANKS}

Among the challenges that have confronted small banks since the mid-1980s have been a wave of bank mergers and acquisitions, the continued rise in nonbank competition for customers, and a decline in the real value of deposit insurance. Mergers reduced the number of banks in the United States from more than 14,000 in 1985 to about 8,300 at the end of 2000 (chart 1, top panel). Although many mergers since the mid-1990s liberalization of banking laws have involved reorganizations within existing bank holding companies, the number of such banking organizations also has fallen over the 1985-2000 period, from about 11,000 to less than 7,000. Mostly as a result of mergers, the share of domestic banking assets held by the largest 100 banks (hereafter, large banks) rose from about 50 percent to more than 70 percent during the period (chart 1, bottom panel). The bulk of the gain came at the expense of small banks-those not among the 1,000 largest; their share of assets fell from about 25 percent to just over 10 percent.

A merger would tend to improve the competitive position of the surviving institution by adding to the scope of its activities, thus allowing it to offer a larger variety of services and products to customers, and by increasing the diversity of its assets. All else equal, the greater diversification would act to stabilize earnings, thereby reducing the riskiness of the surviving bank and increasing its attractiveness to depositors. Alternatively, the now-larger bank could exploit the greater diversification to maintain the riskiness of the institution around pre-merger levels while adjusting its portfolio toward higher-yielding assets, thus boosting profitability. ${ }^{2}$

2. Some research has found that banks do exploit greater diversification in this way. For more information, see Rebecca S. Demsetz and Philip E. Strahan, "Diversification, Size, and Risk at Bank Holding Companies," Journal of Money, Credit, and Banking, vol. 29 (August 1997), pp. 300-13; and Jalal D. Akhavein, Allen N. Berger, and David B. Humphrey, "The Effects of Megamergers on Efficiency and Prices: Evidence from a Bank Profit Function," Review of Industrial Organization, vol. 12 (February 1997), pp. 95-139. 
1. Number of banks, and industry concentration by asset size of banks, 1985-2000

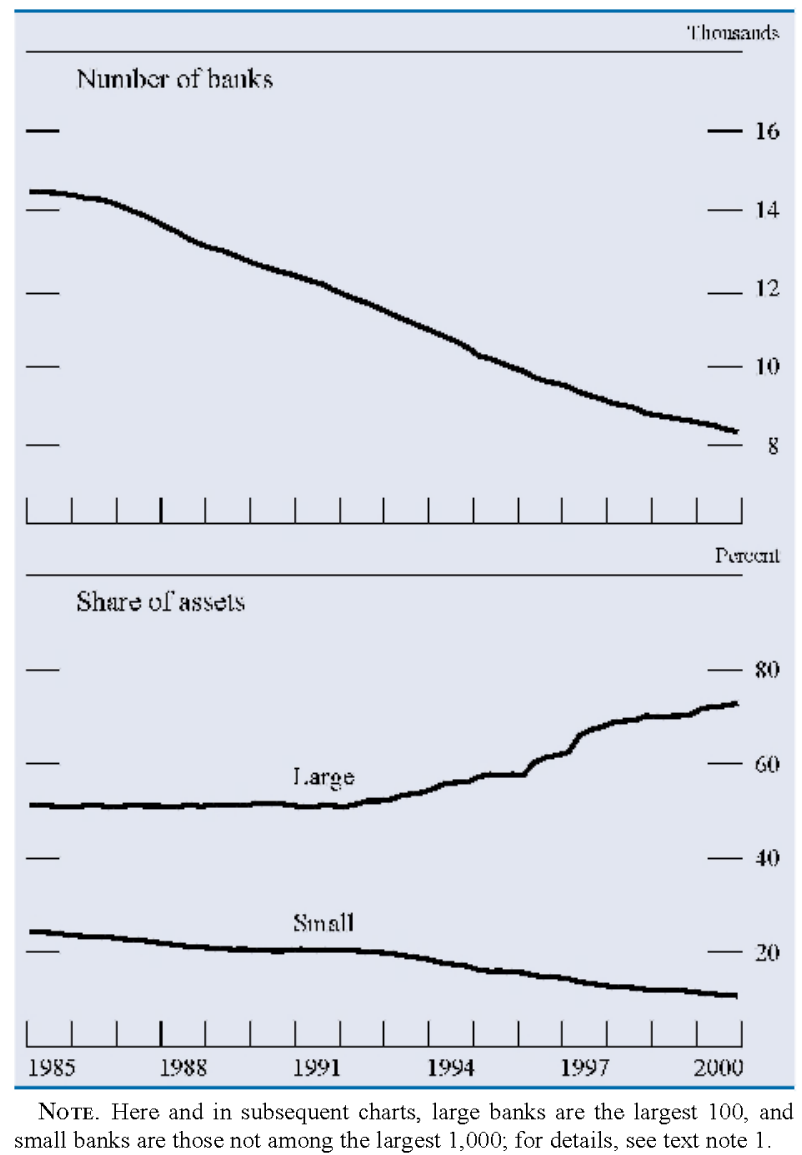

The competitiveness of the largest banks would also be improved if depositors believe that the government will treat these banks as "too big to fail," and the perceived advantage would be greater still in the context of declining real levels of deposit insurance. ${ }^{3}$ However, the Federal Deposit Insurance Corporation Improvement Act of 1991 substantially circumscribed the ability of regulators to use too-big-tofail by requiring that the Federal Deposit Insurance Corporation (FDIC) pursue the resolution method that minimizes the cost to its insurance fund. In addition, exceptions to the "least cost" method are allowed only with the approval of at least two-thirds of both the Federal Reserve Board and FDIC board of directors and the approval of the Secretary of the

3. The nominal value of deposit insurance was last increased in 1980 , and by a substantial amount-from $\$ 40,000$ to $\$ 100,000$. By the end of: 2000 , the value of: the insurance in 1980 dollars had fallen to between $\$ 45,000$ and $\$ 55,000$, depending on the price index used, and therefore was in real (inflation-adjusted) terms still slightly higher than it was just before the 1980 increase.
Treasury in consultation with the President. Moreover, bank regulatory agencies maintain that no bank is too large for shareholders and holders of the bank's nondeposit liabilities to face complete loss, should the decline in bank asset values be large enough, and for uninsured depositors to be subject to less than 100 percent reimbursement. ${ }^{+}$

Besides the effects of consolidation and a decline in the real value of deposit insurance, increasing competition from a "parallel banking system" may have weakened the competitive position of small banks since the mid-1980s.5 On the liability side of the balance sheet, banks compete with stock, bond, and money market mutual funds for deposits. Although mutual funds compete with banks of all sizes, they likely pose a greater competitive challenge to small banks, which are more dependent on deposits than are large banks. Given their high liquidity and their record of preserving the par value of their investors' assets, money market mutual funds represent a particularly attractive alternative to bank deposits. ${ }^{6}$ About one-third of money fund assets consist of commercial paper issued by finance companies, which, in turn, compete in markets for consumer loans and business equipment financing, markets that may be more important for small banks than for large banks.

Nonetheless, consolidation in the banking industry may have had some beneficial aspects for small banks. For example, some large banks may find that they lack the knowledge and experience necessary to compete effectively in the local loan markets of the smaller banks they have acquired. Similarly, on the funding side, bank depositors may react adversely to acquisitions of their banks by out-of-area institutions and move their deposits to a locally headquartered small bank. ${ }^{7}$

Some other recent developments have also favored small banks. The scaling back of the savings and loan

4. See speech by Alan Greenspan, Chairman, Board of Governors of: the Federal Reserve System at the 37th Annual Conference on Bank Structure and Competition of the Federal Reserve Bank of: Chicago, Chicago, Illinois, May 10, 2001 (www.federalreserve.gov? boarddocs/speeches/2001).

5. See Jane W. D'Arista and Tom Schlesinger, "The Parallel Banking System," in Gary A. Dymski, Gerald Epstein, and Robert Pollin, eds., Transforming the US. Financial System: Equity and Efficiency for the 21 st Century (M.E. Sharpe, 1993), pp. 157-99.

6. On only a few occasions has the net asset value of a money market mutual fund threatened to dip below $\$ 1$, and in all but one of: the cases, the funds avoided "breaking the buck" by receiving assistance from their parent companies.

7. For more information, see Steven J. Pilloff and Stephen A. Rhoades, "Do Large, Diversified Banking Organizations Have Competitive Advantages?" Review of Industrial Organization, vol. 16 (May 2000), pp. 287-302. 
industry during most of the period probably reduced the competitive pressures on small banks. Moreover, depositors may not have been particularly concerned about the declining real value of deposit insurance in recent years given the strong economy, the high profitability of banks, and very low bank failure rates. Supporting this view are the continued strong growth of money market mutual funds, which have no federal insurance program comparable to that for bank deposits, and the rapid growth of uninsured deposits, particularly at small banks.

\section{DIFFERENCES IN THE LIABILITY STRUCTURES OF. SMALL AND LARGE BANKS}

Not surprisingly, small banks rely on deposits considerably more than large banks do. In particular, small time deposits (those issued in amounts of less than $\$ 100,000)$ funded almost 30 percent of loans and other assets at small banks in 2000 , while at large banks the share was about 10 percent (table 1). The share of small banks' assets funded with large time deposits, 13 percent, also exceeds that at large banks, 8 percent. $^{8}$ Other interest-bearing deposits, which consist of savings and transactions accounts, also were somewhat more important funding vehicles at small banks, while non-interest-bearing deposits

8. Large time deposits are those of at least $\$ 100,000$. Deposits of exactly $\$ 100,000$ would be fully insured as to principal. funded comparable shares of small and large banks' assets.

Large banks fund about one-third of their assets with "other" nondeposit liabilities, whereas at small banks the share is just 3 percent." Small banks avail themselves somewhat more of FHLB advances, although these represent a fairly small share of liabilities at both groups of banks. Equity also funds a larger share of assets at small than at large banks, 10.3 percent and 8 percent respectively.

Reliance on deposits was little changed between 1987 and 1992, but both bank groups shifted toward nondeposit liabilities and capital as sources of funding during the 1990s. Between 1992 and 2000, deposits as a share of assets fell about 4 percentage points at small banks and 11 percentage points at large banks. For both bank groups, "other interest-bearing deposits" was the deposit category that fell most sharply in the 1990s; small time deposits (which are fully insured) also declined at both bank groups, a drop probably reflecting the increased popularity of alternative household investment vehicles such as mutual funds. However, the share of assets funded by large time deposits actually increased at both bank groups.

9. Other liabilities consist of demand notes issued to the U.S. Treasury, federal funds purchased and securities sold under repurchase agreements, trading liabilities, net due to related institutions abroad, subordinated debt or debentures, and bankers acceptances.

1. Distribution of assets at banks, by source of funds, selected years, 1987-2000 Percent

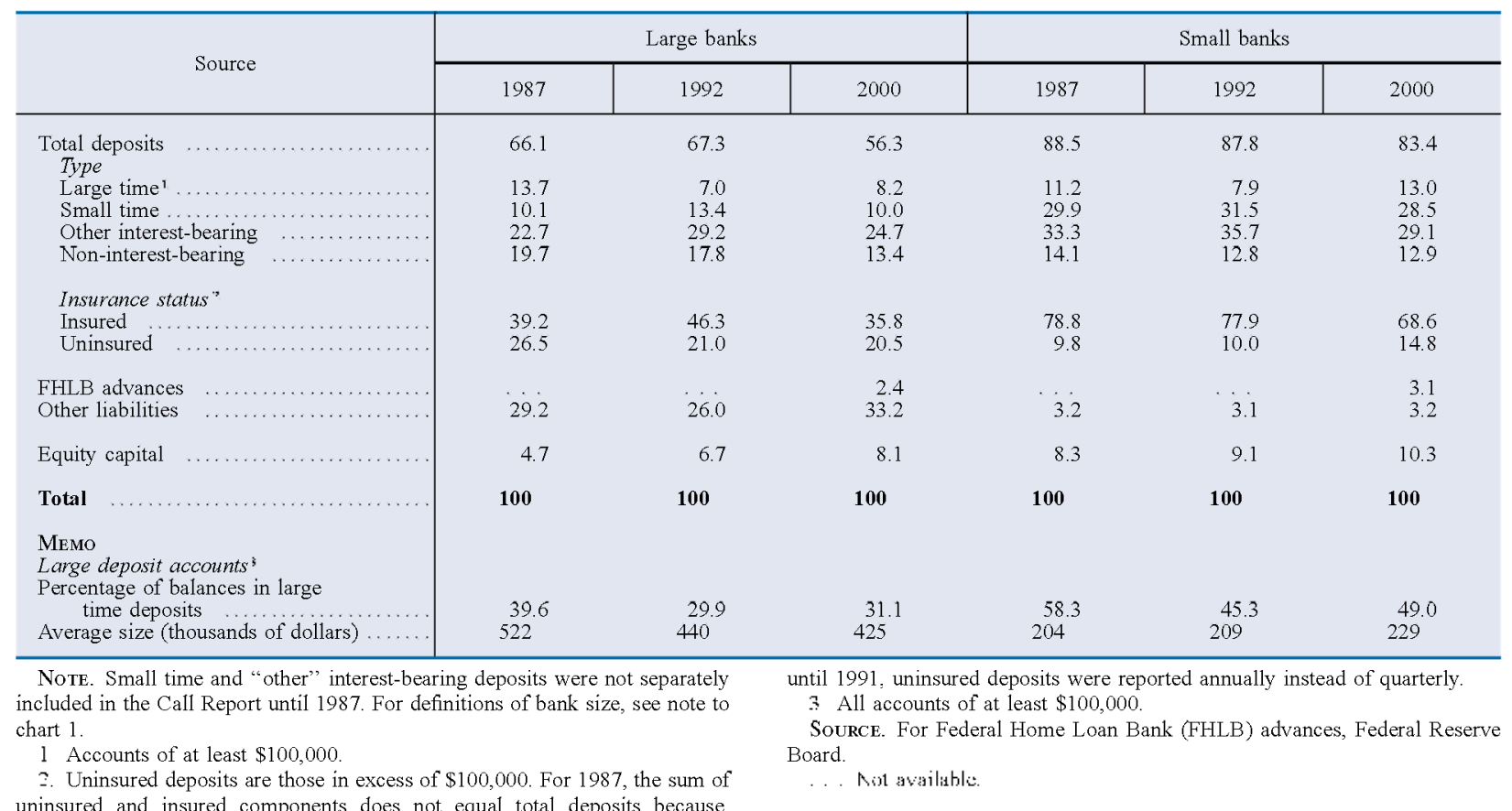


At small banks, the type and average size of large deposit accounts (those of at least $\$ 100,000$ ) are notably different from those at large banks (table 1 , memo). At large banks, only about 30 percent of such balances were held as large time deposits in 2000; the remaining 70 percent were in transaction and savings accounts. At small banks, large balances are split about evenly between large time and other deposits. The average size of large deposits at large banks in 2000 was $\$ 425,000$, and at small banks it was $\$ 229,000$; however, over the 1990 s the average size has been declining at large banks and rising at small banks.

\section{DIFFERENCES IN THE GROWTH PATTERNS OF LARGE AND SMALL BANKS}

The consolidation in the banking industry over the 1985-2000 period typically involved the acquisition of relatively small banks by much larger banks, a development that, of course, boosts the observed growth of large banks and diminishes that of small banks. Therefore, the differences in the balance-sheet growth and profitability between large and small banks cannot be consistently tracked unless mergeradjusted balance sheet and income data are used..$^{10}$

Balance sheet data adjusted for mergers show that small banks generally grew faster than either medium-sized or large banks over the past fifteen years (chart 2, top panel). Indeed, in every year, the growth of assets has been significantly faster at small and medium-sized banks than at large banks. " Of course, banks securitize and sell a significant portion of the consumer and real estate loans that they originate and thereby move them off their balance sheets. But data available since 1997 indicate that restoring securitized credit card loans to large banks' balance sheets would add only about 1 percentage point to their annual asset growth in 1998, and less than that in 1997 and 1999, not enough to narrow the differ-

10. We calculate merger-adjusted growth for any bank size group by comparing balance sheet values at the end of the quarter with those at the beginning of the quarter, accounting for amounts acquired or lost during the period because of mergers. For example, we calculate asset growth at small banks during a quarter by comparing assets at the end of the quarter with assets at the beginning of the quarter after removing assets acquired during the quarter by merger. Mergeradjusted annual growth rates are calculated as the product of mergeradjusted quarterly growth rates. For information on the adjustment procedure for income, see the appendix in William B. English and William R. Nelson, "Profits and Balance Sheet Developments at U.S. Commercial Banks in 1997," Federal Reserve Bulletin, vol. 84 (June 1998), p. 408.

11. Calculated without adjusting for mergers, the average annual growth rate of assets between 1985:Q4 and 2000:Q4 was 0.2 percent for small banks and 8.2 percent for large banks.
2. Growth of assets and deposits, by asset size of banks, $1985-2000$

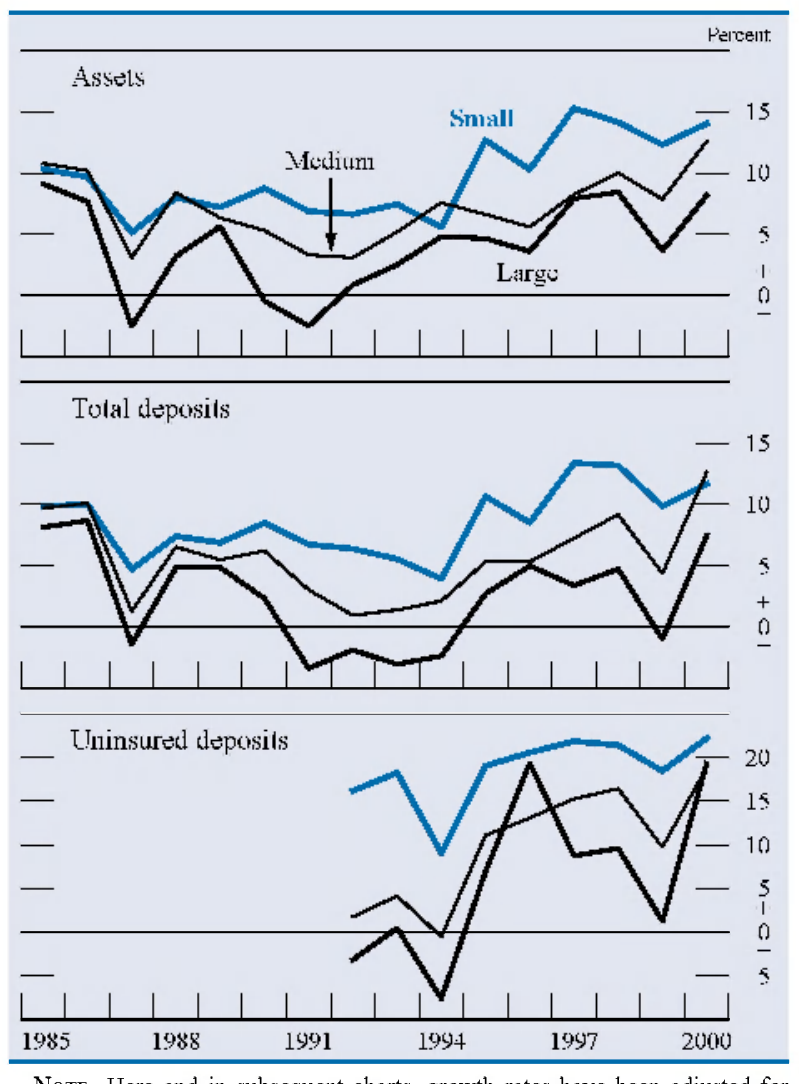

NoTE. Here and in subsequent charts, growth rates have been adjusted for mergers; for details, see text note 10. Medium-sized banks are those ranked 101 to 1,000 . Uninsured deposits are those in excess of $\$ 100,000$; before 1991 , uninsured deposits were reported only annually. which prevents merger adjustment of balances for those years in a manner consistent with quarterly adjustments applied in later years.

ence in growth rates significantly. ${ }^{12}$ In 2000 , such an adjustment would have reduced the measured growth of large banks.

Many more new, or "de novo," banks were formed during the 1997-2000 period than during the preceding four-years (moving from about 150 per year to about 350 per year on average). Although de novo banks tend to grow rapidly, they are generally very small when established (less than $\$ 50$ million in assets). Thus, the growth rate of all small banks is not significantly affected if de novo banks are excluded from the calculation.

As suggested by the relative rates of asset growth, the expansion of total deposits at both small and medium-sized banks has also exceeded the growth rate at large banks in every year since 1985 (chart 2, middle panel). However, the growth of assets tended

12. Adding securitized assets to the balance sheet for purposes of comparison presumes that the securitizing bank still would have chosen to originate the loans even if the opportunity to securitize was not available. 
3. Growth of assets and deposits at small banks, by asset size of banks, 1985-2000

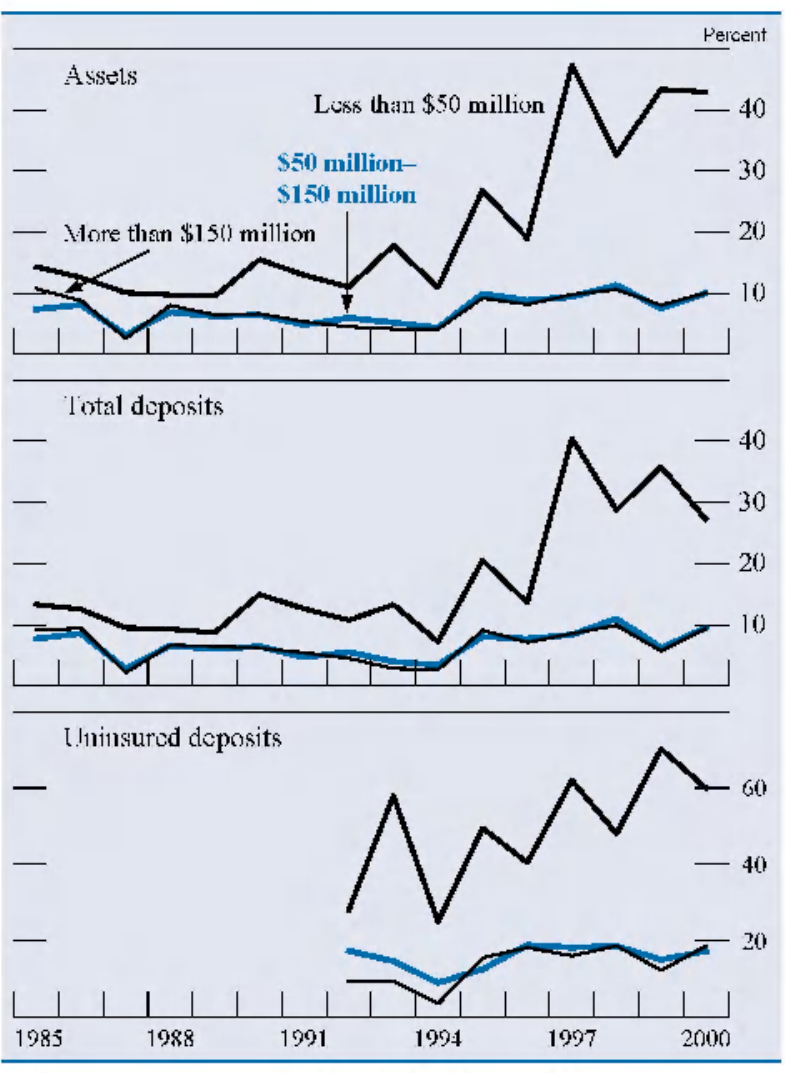

Note. For measurement of uninsured deposits, see table 1 , note 2

to exceed that of deposits, as the use of nondeposit liabilities grew for all bank size groups. Uninsured deposits also grew significantly faster at small banks than at large banks (chart 2, bottom panel). Furthermore, the growth rate of uninsured deposits at small banks has been high and steadily increasing during the second half of the past decade, whereas at larger banks the growth of these liabilities shows no trend.

The fastest growing category of small banks has been the smallest among them - those with less than $\$ 50$ million in assets (chart 3, top and middle panels). The 1997-2000 rise in the growth of assets and deposits at these banks was strong even after adjusting for the formation of de novo banks. The smallest of the small banks have aggressively acquired uninsured deposits to help fund their expansion (chart 3, bottom panel). Although small banks with assets of more than $\$ 50$ million grew more slowly than the smallest banks, they still grew faster than large banks.

Another way to disaggregate small banks is by location. Doing so reveals that growth has been the fastest among urban banks and the slowest among rural banks with high concentrations of agricultural loans; the growth of other small banks in rural areas
4. Measures of balance-sheet health, by asset size of banks, 1985-2000

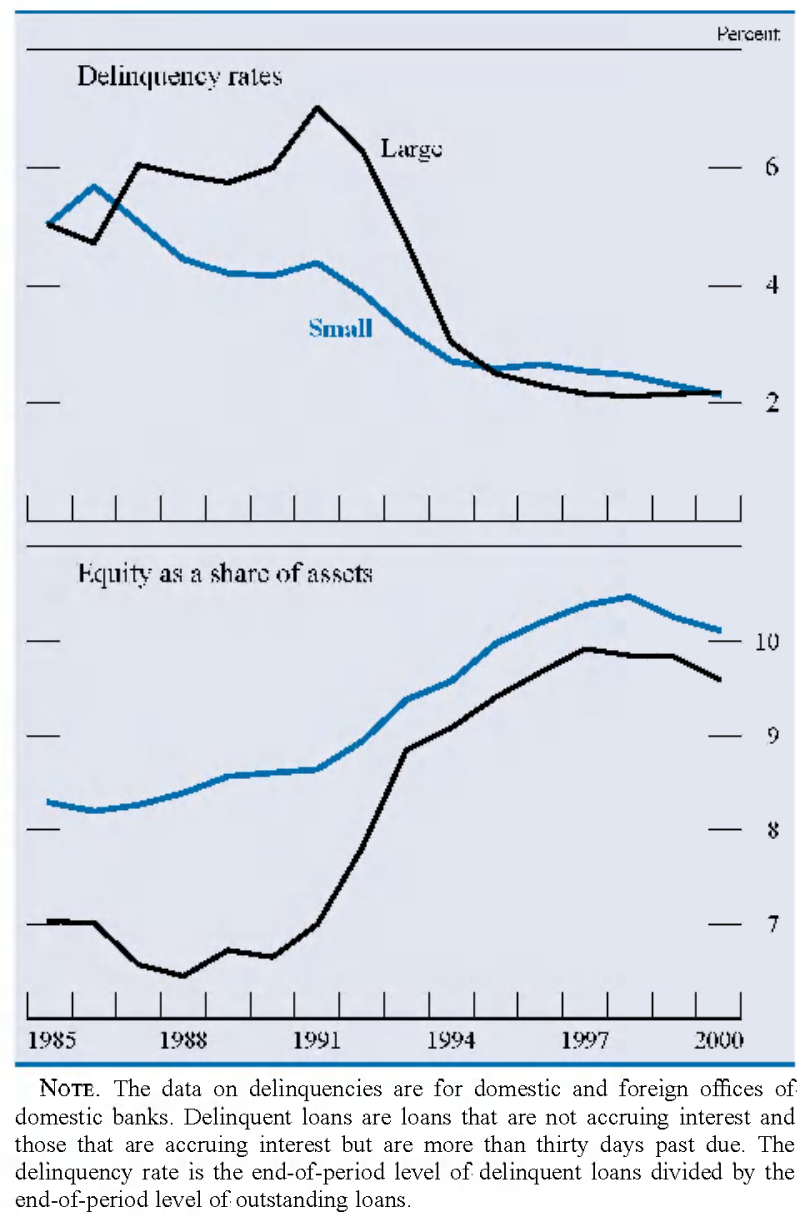

falls in between. However, even agricultural banks tended to perform at least as well as large banks over the period studied (see box "Rural and Agricultural Banks").

The growth patterns of large and small banks partly reflect changes in their overall balance sheet conditions and fluctuations in the business cycle. Both large and small banks were major suppliers of credit during the final years of the $1980 \mathrm{~s}$, when businesses and households were rapidly accumulating debt. By the early 1990s, a weak economy as well as high debt levels and a rising volume of delinquent loans significantly slowed spending and borrowing by businesses and households. The slowdown in the growth of bank assets and deposits at that time was most pronounced at medium-sized and large banks, however, with assets actually declining for a time at bigger banks.

The contraction of assets at large banks may be attributable to the fact that overall asset quality deteriorated in the late 1980 s and especially during the 1990-91 recession (chart 4, top panel). At small 
5. Spread of interest rates paid and spread of growth rates of deposits, small banks less large, 1985-2000

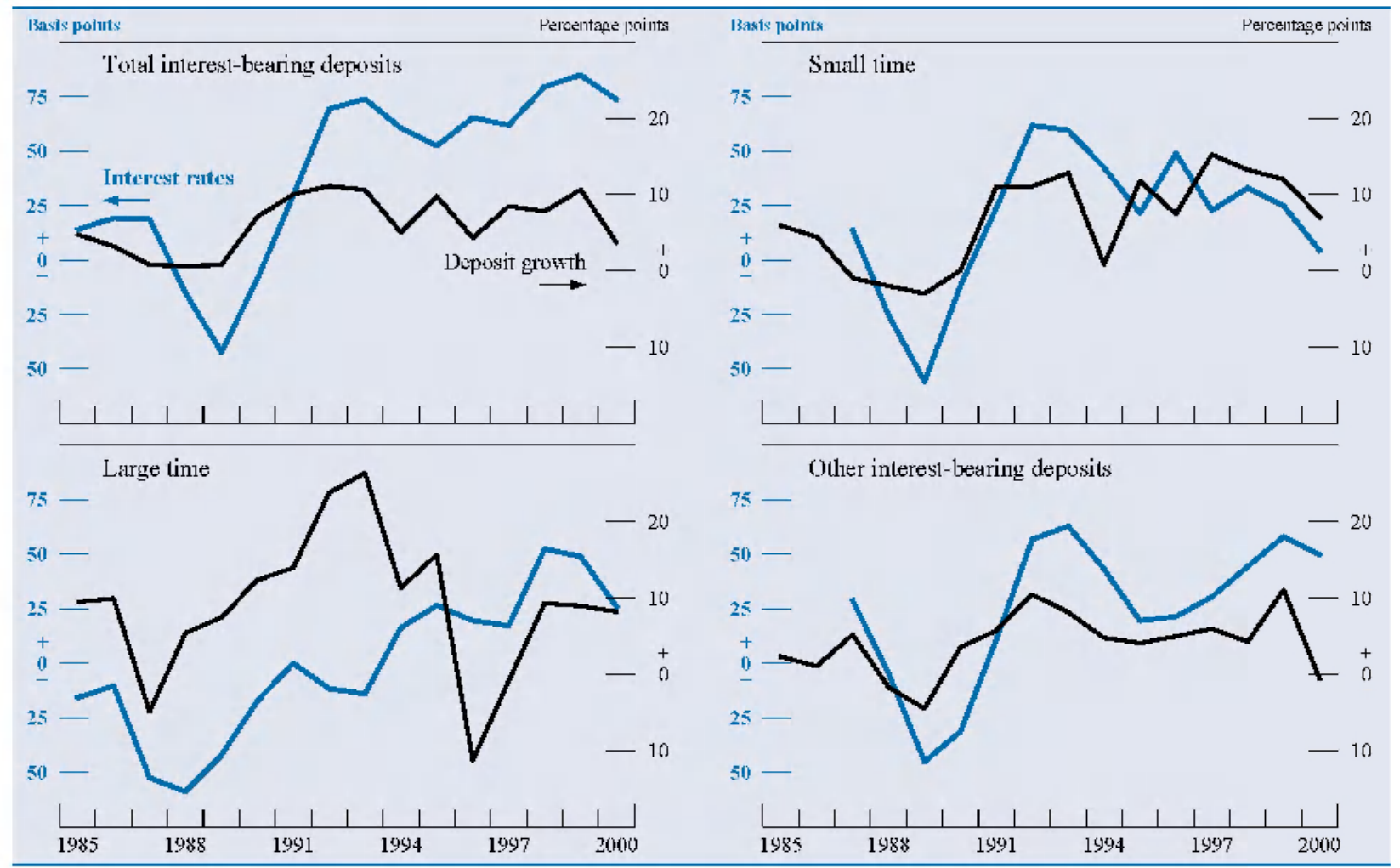

NotE. Rates paid on small time deposits and on "other" interest-bearing deposits were not separately included in the Call Report until 1987.

banks, the recession precipitated only a slight rise in delinquency rates. As loan losses mounted at large banks in the late 1980s and early 1990s, they found themselves with depleted capital (chart 4 , bottom panel). Hence, a substantial gap appeared to emerge between their actual capital levels and those being demanded by markets as well as by regulators acting under the 1991 Basel Accord.

The subsequent economic recovery and brisk expansion of the second half of the 1990 s caused delinquency rates to drop at both bank size groups, but much more dramatically so at large banks. A somewhat similar picture emerges for capitalization measures: Although the ratio of equity to average tangible assets (the "leverage ratio") at large banks remained well below that at small banks throughout the 1985-2000 period, the gap narrowed noticeably during 1992 and 1993, and the gain was maintained over the rest of the decade (chart 4 , bottom panel). ${ }^{13}$

13. The ratio of equity to assets is shown here because it can be computed for the years preceding the implementation of the Basel Capital Accord, in 1991. Small banks also have significantly greater capital ratios than large banks when measured by risk-weighted assets, a characteristic that may, in part, reflect the higher risk inherent in the relatively less diversified loan portfolios at small banks and their more limited access to markets for managed liabilities.
The large banks' impressive recovery from the deep problems of the early 1990s could be expected to have boosted their competitive position, and indeed the recovery in loan growth in the latter half of the 1990s was a bit stronger at large banks; yet during all of this period, the growth of assets at small banks surpassed that at large banks.

\section{THE EXPANSION OF DEPOSITS AT SMALL BANKS: RELATIVE OFFERING RATES AND RELATIVE DEPOSIT GROWTH}

The growth of total interest-bearing deposits at small banks consistently exceeded that at large banks between 1985 and 2000; the difference tended to reflect the difference between deposit interest rates paid at small banks and the rates paid at large banks (chart 5, top left panel). ${ }^{14}$ Early in the period, small banks were outbidding large banks for deposits; the

14. Average interest rates on deposits are computed as quarterly interest expenses, annualized, as a percent of average deposits held over the quarter. Annual rates are averages of quarterly rates. Both average deposit levels and deposit expenses are calculated after adjustment for mergers. 
6. Return on loans, by assets size of banks, 1985-2000

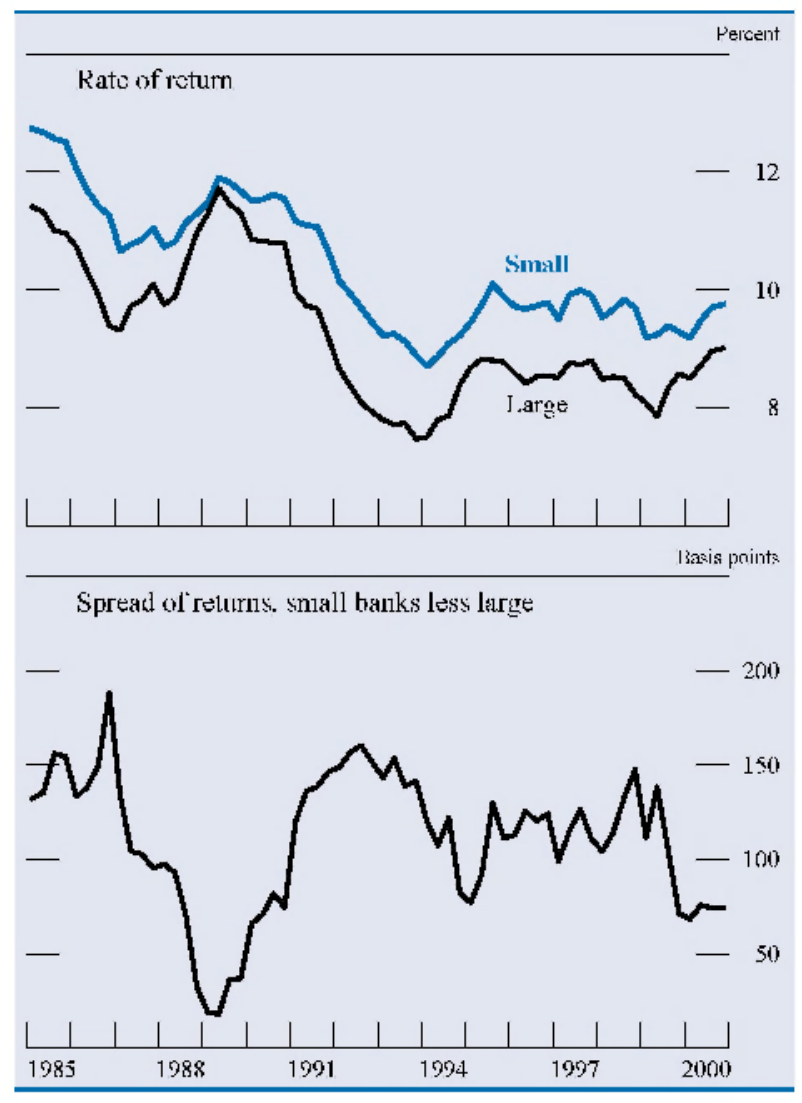

reversal of this relationship in the late 1980s and into 1990 seemed to prompt a relative speedup of growth of deposits at large banks. In the 1989-93 period, the average rate paid on interest-bearing deposits at small banks rose about 1 percentage point relative to rates at large banks, thereby about tripling the premium paid by small banks in the mid-1980s. In response, the growth rate of deposits at small banks rose substantially compared with that at large banks.

The spread of deposit rates at small banks over those at large banks remained elevated and even increased somewhat over the course of the 1990s, but the corresponding spread for deposit growth did not keep pace. The relationship between rates and deposit growth loosened because of large time deposits, for which the growth spread tended to diminish even as the interest rate spread trended up (chart 5, bottom left panel). For small time deposits, by contrast, the underlying relationship between relative offering rates and deposit growth does not seem to have shifted over the period (chart 5, top right panel). In the "other interest-bearing deposits" category, the relationship weakened substantially in 2000 , largely because of special factors that boosted the growth of insured deposits at large banks during the final quarter of last year (chart 5, bottom right panel). ${ }^{15}$

These patterns of deposit growth and deposit offering rates at large and small banks raise two questions. First, why did small banks choose to pay premium rates on their deposits to fund asset growth that was faster than at large banks? Second, why did the additional deposit growth become progressively more expensive? The first question would seem to be answered straightforwardly by the fact that small banks have been able to make loans that have consistently yielded more than loans at large banks (chart 6). ${ }^{16}$

As to the relative rise in the cost of deposits at small banks, a number of factors appear to have been in play. First, small banks have a more limited base from which to attract funding. Thus, at small banks, the marginal supply of funding is likely to be more dependent on deposit offering rates than it is at large banks because large banks can more easily tap nondeposit funding sources and thereby minimize the impact on rates in any one category of liabilities. Combined with the relatively greater need of small banks for deposits to fund stronger loan demand, a relatively narrow funding base would help to explain the comparative increase over time in the cost of deposits to small banks.

A second likely reason for the rising relative cost of attracting deposits at small banks is the improvement in balance sheet health at large banks, which in turn presumably lowered the risk premiums they paid on their deposits, especially on uninsured deposits. Still another factor could have been the sliding real value of deposit insurance. This decline would have required all banks to rely less on insured deposits, but these deposits are more important at small banks than at large banks. Moreover, a shrinkage in the real value of deposit insurance could have magnified the effect of the relative improvement in balance sheet health at large banks. The drop in the real level of insurance coverage would also have added to the advantage that the largest banks enjoy from whatever credence depositors may still give to the notion of "too big to fail."

15. On behalf of its clients, a large brokerage house transferred funds from (uninsured) money market mutual funds to insured money market deposit accounts at its affiliated commercial banks during the fourth quarter of 2000 . The transfers significantly boosted the growth of insured deposits at large banks.

16. The higher gross rate of return at small banks may reflect, in part, higher loan processing costs (per loan dollar), although advances in technology have no doubt lowered such expenses throughout the period studied. 


\section{Rural and Agricultural Banks}

Growth at small banks over the 1985-2000 period has varied somewhat by bank type and location. In particular, loans and securities (bank credit) have grown consistently more slowly at small agricultural banks than at other small rural banks or at the clear growth leaders among small banks-the small urban banks (chart, upper left panel). ${ }^{7}$

1. Small banks are classified as "urban" if they are headquartered within a Standard Metropolitan Statistical Area. Small "rural" banks are divided into "agricultural" banks (those with more than 25 percent of their loans that are secured by farmland or used to finance agricultural production) and "other rural" banks
Also, credit growth during the 1990s at small urban and other rural bank groups has consistently exceeded that at large banks, but the record of the small agricultural banks has been mixed.

Developments in the agricultural sector itself appear to explain much of the underperformance of agricultural banks relative to large and other small banks. The slow growth of farm business debt relative to all nonfinancial business debt over the past several years (chart, upper right panel) suggests that the demand for agricultural loans has lagged substantially behind the demand for other bank loans. More-

Performance of banks, by asset size and sector, and growth of nonfinancial business debt, 1985-2000

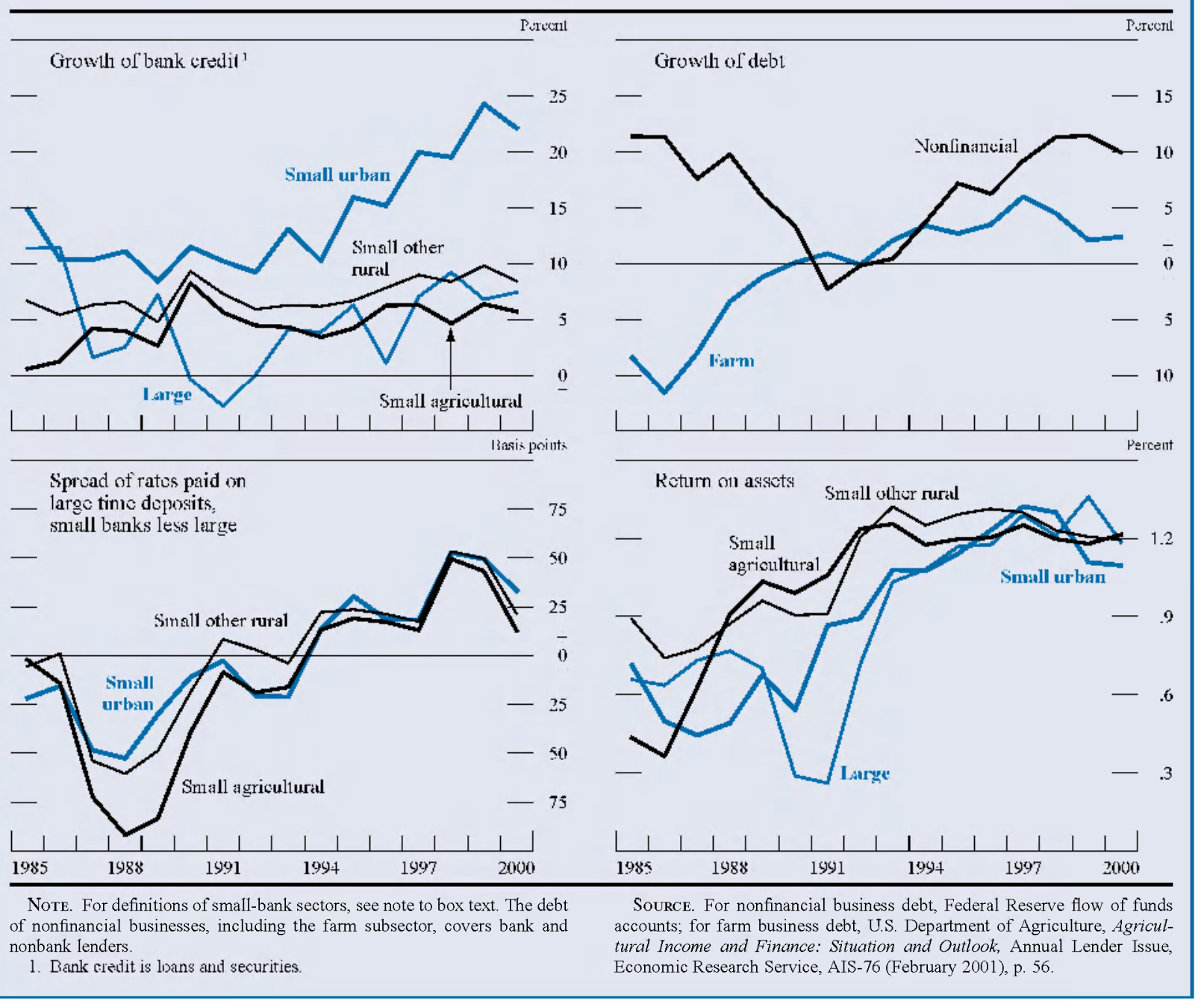

Finally, more attractive deposit substitutes, such as mutual funds, were growing briskly throughout the 1990s. The competition that banks had from mutual funds was offset to some degree by problems in the thrift industry, where assets declined 26 percent

between 1989 and 1997. But the fact that more than half of the decline had been reversed between 1997 and 2000 suggests that the thrift industry's competitive pressure on banks had begun to re-emerge in those years. 


\section{Rural and Agricultural Banks-Continued}

over, commercial banks' share of farm business debt continued to increase during the past five years, although at a slower rate than in the late 1980s and early 1990s (data not shown). The slowing reflects, in part, a pickup in market share by the Farm Credit System over the same period as it recovered from financial difficulties in the 1980s.

Although rates of credit growth have diverged among small bank sectors, the sectors converged in terms of the spread of the average interest rates they paid on large time deposits (chart, lower left panel). Small urban banks have been paying only slightly greater premiums on these deposits than small rural banks despite having much higher average growth rates, a difference that presumably reflects more robust economic growth in urban areas.
Yet the increase in interest expense at small agricultural banks relative to large banks does not appear to have been especially damaging to the profitability of the agricultural banks (chart, lower right panel). Measured by return on assets, profitability at agricultural banks has generally been better than at small urban banks and, until recently, at least as good as at large banks.

In sum, although credit has grown most rapidly at small urban banks, and small agricultural banks are not paying much less for large time deposits than are other small banks, the agricultural banks during the 1985-2000 period generally performed at least as well as the largest banks in terms of asset growth and measures of profitability

\section{IMPLICATIONS FOR PROFITABILITI}

The interaction of changes in rates earned on assets with rates paid on liabilities is captured in the behavior of banks' net interest margin. ${ }^{17}$ During most of the $1990 \mathrm{~s}$, the relative cost of deposits at small banks rose (chart 5), yet their net interest margin held steady while the net interest margin for large banks drifted down (chart 7, upper left panel). The steady returns at small banks suggest that the better yields they were able to get on loans made up for the higher rates they had to pay for deposits. Small banks also expanded the share of their portfolios held as loans throughout the $1990 \mathrm{~s}$, whereas the share of loans in the portfolios of large banks has remained more or less stable since 1995 (chart 7, top right panel). Because loans typically earn more than securities, this change in relative portfolio structure also would tend to boost net interest margins at small banks. Since 1997, the net interest margin has fallen at both small and large banks, but margins are still much higher at small banks.

Turning to broader measures of profitability, the return on equity (ROE) at large banks stabilized at an average of about 15 percent throughout the latter half of the 1990s after fluctuating widely during the late 1980s and early 1990s (chart 7, bottom left panel). Small banks' return on equity was also fairly stable during the 1990s and was uniformly above the returns earned during the latter half of the 1980s. ROE at large banks has been significantly greater than at

17. Net interest margin is defined as the difference between interest income and interest expense divided by average interest earning assets. small banks since 1992, but the difference largely reflects the greater levels of capital relative to assets held by small banks.

In terms of the return on assets (ROA), small banks have generally been more profitable than large banks (chart 7, bottom right panel), an achievement that is especially impressive given the greater (and growing) earnings on off-balance-sheet activities at large banks. Indeed, the jump of large banks' ROA over that of small banks in 1999 is attributable to large gains in revenue from capital markets business and trading operations; such revenue is not a significant portion of income at small banks.

\section{SUMMARY AND CONCLUSIONS}

Generally, small banks have thrived over the past decade and a half despite what might be seen as a variety of adverse circumstances, including extensive bank consolidation, a solid improvement in the balance sheet health of large banks, rapid growth in mutual funds and other elements of a "parallel" banking system, and a steady decline in the real value of deposit insurance. Despite these circumstances, and abstracting from the effects of mergers and acquisitions, small banks have grown considerably more rapidly than large banks and have tended to meet or exceed them in some measures of profitability. Although small banks that are concentrated in agricultural lending have grown more slowly than other small banks, overall credit demand in the agricultural sector likewise has been relatively subdued. The robust growth and high profitability we find at small banks apparently have not gone unnoticed by the 


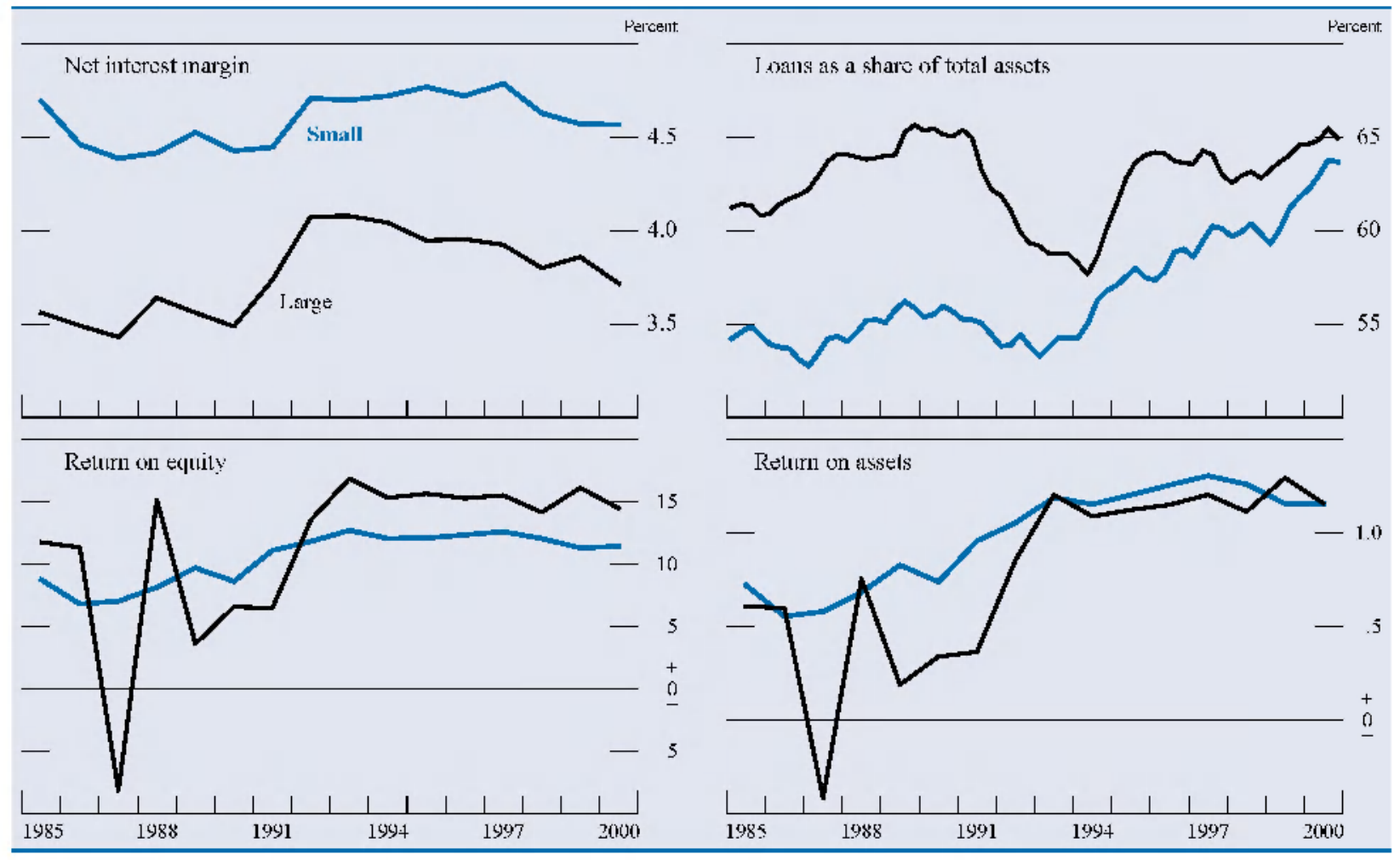

Note. Net interest margin and the returns on equity and assets are for domestic and foreign offices of domestic banks; loan share is for domestic offices only.

investors that have formed significant numbers of new banks in recent years.

As small banks have increased their deposit rates relative to those at large banks, they have generally enjoyed a relative increase in deposit growth. However, in the large time deposit category-where the majority of funds are uninsured - the ability of small banks to increase the flow of deposits by pushing up interest rates has diminished somewhat over time. A significant factor in the diminishment was the more rapid growth of balance sheets at small banks combined with their relatively more limited funding options. Also contributing was the return to health of the large bank sector and, more recently, of the thrift sector. The decline in the real value of deposit insurance presumably also played a role but one that would have been limited after the early 1990s by sharp declines in the rate of bank failures. 